\title{
International and Regional Organizations in the Balkan, the Case of Kosovo
}

\section{Arif Riza}

\author{
Dean of Law Faculty, Professor, University of Prizren "Ukshin Hoti", Prizren, Kosova
}

\section{Adrian Leka}

PhD, "Luigj Gurakuqi" University, Shkoder

Doi:10.5901/ajis.2016.v5n2p163

\section{Abstract}

\begin{abstract}
Before talking to international and regional organizations, I will briefly tell you the history of the establishment of International Organizations and Regional Organizations. All International Organization are classified by their field of activity (around the globe in one or more continents), by their activity (military, political, economic, financial, etc.); in thedecisionmaking ways (only a number of member states in the relevant organs of the organization), to the time of operation (permanent or temporary) etc. In this paper I shall try to give an overview of the functioning of organizations ranging from membership (type of membership), dismissal, suspension and the rights and obligations of members; financing, the immunity and privileges of diplomatic staff in International Organizations. Certainly in this paper I will attempt to explain the role of Regional Organizations in particular on the Balkans including Kosovo. Today International Organizations became an important part of the economyin one country or regionand it plays a major role in the development and democratization of countries. Today without the existence of International Organizations the objectives of states, could hardly be achieved. The paper is based on the research and referring to various contemporary books, resources from the official website addresses, various journals and scientific articles.
\end{abstract}

Keywords: International Organizations, Regional, Government, Non-Governmental Conferences, Conventions, Interstates, Subjects.

\section{International Organizations}

The initial ideas for International Organizations we meetduring the efforts to maintain peacein the countries during the earliest years, but according to their period of establishment and alsotheir role we can make classification as follows: early middle ages, late middle agesand the modern time.

In the early middle ages, or in the Pre Classical Time, best known is Convention of Kadesh between the Pharaoh Ramses II and King Hattusi II, who aimed to preserve the Community Government. A similar relationship of old middle ages wasDelfis ${ }^{1}$ Interaction which was a religious link between Greek states - cities for protection of the Divine Empire. In classic antiqueSimahiti and Military Alliance were popular too. Other connectionsduring this areawaslinks between city-states around Rome, known as PaxRomana².

In the Middle ages (from XI century), following history changes, getting Constantinople by the Ottomans, western countries mainly from with German descent, considered necessary toreactivate the PaxRomana ${ }^{3}$ so they established Christian Empire. At this time there were rough wars between the papacy and the empire, but the greatest danger was coming by outside, so theyconsidered necessary to create the Universal Monarchy for all Christian kings. In the Middle ages must be emphasized the connectivity between Hanse towns, which were more like trading connections in Utrecht Congress year 1713-1714.

In the Modernages (of century XVIII), it is necessary to divide the New agesuntilbeginning of World War II and the New ages after the end of World War II.

${ }^{1}$ There was an Union during 478-404 and again during 378-338 before new ages. Read for more at:Archer, International Organizations 2004 page5

${ }^{2}$ Read more on: RizaArif, E Drejta e OrganizataveNdërkombëtaredheOrganizatatNdërkombëtare, Ipublishment, page 15-16, GrudaZenullah, e DrejtaNdërkombëtarePublike, page 345

${ }^{3}$ PaxRomana once has happened before New ages and the second attempt was in XVI century from the German countries of catholic empire. 
In the Modernages (until the beginning of World War II) as the most significant event where we have the first element of International Organizations is the Congress of Vienna of the year of $1815^{4}$, from which Congress were issued many regulations of International Law,founding River Commission,then the Holy Alliance ${ }^{5}$, but is worth mentioning that in this Congress it was established the German Federation (Deutsche Bund), which was replaced by the German Empire. In this time we have the Congress of Aachen ${ }^{6}$, The Congress of Paris ${ }^{7}$, The Peace Conference of Hague I ${ }^{8}$ and the Peace Conference of Hague ${ }^{\prime}{ }^{9}$.

The Establishment of the 1st Non-Governmental Organization dates from 1840 with the issuance of the International Convention against slavery, whereas in 1844 we have the establishment of the YMCA- Young Mens Christian Association) ${ }^{10}$. In this period we have the formation of a large number of unions (the formation of the Union of Telegraph, Postal Unions ${ }^{11}$ ). Greater importance in the history in forming International Organizations obviously has the formation of OAS-Organization of American States ${ }^{12}$. As the first and most important organization of this time was the Organization- Nations ' League ${ }^{13}$. Up to the formation of the Nations' League, International Organizations operated under contractual obligations between member states of the respective administrations. With the formation of the Nations' League, the states went a step forwardand formed an Organization which had greater power, so they were not confined to the administrative structure of the Member States but the organization was given power in creating mechanisms to make decisions even on the sovereignty of member states ${ }^{14}$. After the foundation of the Nations' League, it formed several International Organizations which previously had been organized in various forms and now the League of Nations had adopted the International Organization, e.g. ILO wasestablished in 1919 and adopted as the Nations' League Organization after the formation of this organization.

In the Modern Ages (after the end of World War II), we have the establishment of many International Organizations. But efforts to create International Organizations were active also During World War II, ITO15, UN16. Rapid development time of the International Organizations' is the time after World War II, where was established a large number of International Organizations with different characters (regional, global, political, nongovernmental organizations with a religious character, organizations involving sports, organizations with economic character), but undoubtedly the establishment of United Nations has special importance.

After World War II great development takes establishment of Regional International Organizations, so that in 1949 the establishment of NATO, the Council of Europe in 1949, the European Communities in 1952/58, EFTA 1960, the Warsaw Pact in 195517, CSCE 1975/199 OSCE, etc. EEA in 1992.

${ }^{4}$ ThisCongreswasheldafter the victoryagianst the NapoleonBonaparta, followedwithimprotantdecisions. (For more read the book: Riza Arif, E Drejta e Organizatave Ndërkombëtare dhe Organizatat Ndërkombëtare, i publishment page 25) http://gdz.sub.unigoettingen.de/dms/load/img/?PPN=PPN546672892\&IDDOC=316027

${ }^{5}$ The Aleance thatwasestablishedbetweenfourlargestcountriesof the year 1818 after the AhenitCongres, and France wasoneof them.

${ }^{6}$ The Congress of Ahen was the continue of Congress of Vjena, where few decisions were taken: example: withdrawal of Holy Alliance, prohibition of trading the slaves, the France takes over the reimbursement of damages occurred by Napoleon Bonaparta, etj.

${ }^{7}$ The Congress of Paris was held in 1856, concluding the Declaration for Marine Rights, containing 34 rules.

${ }^{8}$ From this Conference were issued three important declarations.

9In this Conference 13 decision were derived (agreements/conventions) related to the International Law.

${ }^{10}$ Archer, InternationaleOrganisation 2004 page. 12

${ }^{11}$ For more read: ChritianTiejet, InternationalesVerwaltungshandeln, Berlin 2001, page 124

$12 \mathrm{OAS}$ is an old regional organization established at the Conference of Washington on 14 April of 1890, were states agreed to resolve the conflicts through arbitress. This organization continues to be active on technical decision for Organizations.

13 The OrganizationofNations Union was created on 10 January 1920 based on the initiation of former US president Woodrow Wilson. This organization was unsuccessful for many reasons that lead to the World War II. Read more on: RizaArif, E Drejta e OrganizataveNdërkombëtaredheOrganizatatNdërkombëtare, botimi i l, page 147,

${ }^{14}$ Such mechanism was the creation of Permanent Court of Rights, and other divisions of the Organization.

15/TO- International Trade Organization, the organization that was never created, because of the disagreements between countries triumphed during World War II.

${ }^{16}$ During the World War II there was attempt for establishment of International Organizations starting from: Atlantik Rights (1941), Mosk Declaration (1943), Teheran Conference (1943), Dumbarton Oaks (1944), leading to the establishment of UN on 26 June 1945.

${ }_{17}$ The Warshav Pact existed from 1955 until 1991, were the Military Organization leaded by Union of Sovjetik Republic constituted by communist countries .(Shqipëria, Republika Demokratike e Gjermanisë, Çekosllovakia, Rumunia, Hungaria Bullgaria dhe vet RSSR) 


\section{Number of International Organizations}

The number of International Organizations has always been growing, but also the quality of the Organizations has changed depending on the time they were established.

In the XIX century after World War II the number of International Organizations increased significantly. According to the data of the Union of International Associations established in Brussels in 191018, the number of International Governmental Organizations (IGO / IGO) before World War Par was about 30-50 organizations, whereas before World War II , $80^{19}$ was the number of these organizations. International Governmental Organizations after 1900,their number was higher and reached 200, while until 1950 amounted to $800^{20}$. Regarding the number of International Organizations we can find in the books 'volumes "Shenimet per orgaizatatNderkombetare ${ }^{21}$ ("Notes on International Organizations"). According to this book the number of Governmental and Nongovernmental International Organizations in the world reached the number of $34995^{22}$, but the number of Government or Nongovernmental International Organizations is not stable because they can get remitted or establishment of new organizations.

\subsection{Meaning and the establishment of the International Organizations}

When we talk about International Organizations should be given the clear definition of what do wereally mean with International Organization. To give a better definition firstly we must distinguish amongst the Interstate or Intergovernmental Organizations (IGOs Intergovernmental Organization), and Non-Governmental International nongovernmental state or INGOs Organizations). While the first ones are established by the governments of member states through an International agreement (Convention) these second ones are not established by governments or states. For the first ones, National States are their base of establishment, so will depend on the state, while the second are proceeded only to the jurisdiction where they apply for the establishment. However, both types of organizations have common features, e.g. structure (bodies) funding (even though method of financing is changeable), legal acts (while the first ones only on the basis of International Conventions), both are proceeded to the jurisdiction of the establishment, so they have regulations, which are in accordance with the legislation of the country where they are registered.

Based on what was mentioned above we can define that the International Organizations are created by two ${ }^{23}$ or more International Law subjects when subject can be International Organizations ${ }^{24}$ themselves. Traditionally organizations are established based on the International Convention called Founding Agreement or articles of incorporation (whereas there is no matter in the name of the charter which may be different label e.g.: Statute, the Convention, the Constitution, regulation, etc. . $^{25}$ which are created within indefinite time ( despite the Organization that has been established in certain time as was the case with BETHÇ), for different purposes (political, economic, military, social, cultural, etc.).

These Organizations can be limited geographically (European Union), by the form pf actions (p.sh OPECK), or with a number of different topics such (UN)

\subsection{Membership, dismissal and suspension by the International Organization}

\subsubsection{Membership}

Since the Organizations created by the International Law subjects, according to the articles of incorporation they get established with the signature of the member states or after ratification by Member States. Butfrom the international practice we noticed that some organizations are established by und-bodies or by an International Organization such as :

\footnotetext{
18Wallace- Dinger, Intergovermental Organization 1970 page. 243

${ }^{19}$ Karns/Mingst, Internationale Organizations 2010, page. 8 Jacobson, Networks

${ }^{20}$ BoliThomas, Art, INGOs, 1999, f. 14 :Iriy Global Community 2002, page 21,28, 55, White, International Nongovermental Organizations 1968 page. 7

${ }^{21}$ Riza, Arif, E Drejta e Organizatave Ndërkombëtare dhe Organizatat Ndërkombëtare, botimi i I f. 64

${ }^{22}$ http://www.uia.org/sites/dev.uia.be/files/misc_pdfs/ybvol5_lookinside.pdf

${ }^{23}$ For example: the numberofmemberstatesofOrganizationisfrom 3 (NAFTA) until 200 The Universal Postal Union.

${ }^{24}$ For example: European Union ismemberofInternationalTradeOrganizations.

${ }^{25}$ ut there are organizationssuch as the OSCE has nocharterbecauseofalienationfrom the CSCE to the OSCE
} 
by UN bodies is created WIPO26, UNIDO27.

However a state or International Organization to join the International Organization it must meet certain requirements, but generally (depending on the articles of incorporation) those conditions may be of different manners : forma ${ }^{28}$ and material ${ }^{29}$. While member states in the Organization itself have different membership status; full member or regular member ${ }^{30}$ associated or pre members ${ }^{31}$ and monitors ${ }^{32}$, which can also be full and partial monitored.

\subsubsection{Abandonment or leaving the International Organization}

While membership is mutual act therefore it must exist the will of state candidate and the countries which are already members, and therefore leaving the Organization is unilateral act concluded by its member state.

But also when the act of establishment sets procedure when a member may (subject to International Law) abandon $0=$ Organization, in some cases there are conditions set which may be materia ${ }^{\beta 3}$ and time aspects ${ }^{34}$. However there are times when members are dismissed from an organization which may have been dissatisfied for various reasons e.g. from ILO has been removed US, the US from UNESCO, or from UNIDOthe United Kingdom ${ }^{35}$. In international practice there were cases when the act of establishment of the International Organization prohibits the leavefrom the Organization, e.g. Treaty of Amsterdam whereas was forbidden abandonment or dismissal from the EU.

\subsubsection{Exclusion}

Suspension and exclusion are non-voluntary legal unilateral acts of the International Organization made against a member state, which claims to have violated the rules of that Organization. And there were frequent exceptions to the member states at the time of the Nations' League existence, e.g. The Nations'League had ruled Russia due to its aggression against Finland ${ }^{36}$

\subsubsection{Suspension/Suspension}

The suspension is punitive proceedings against a member, who did not fulfil their obligations to the Organization. As exclusion itself, suspension is punitive proceeding of Organization which ones usually are regulated by establishment acts. So e.g.Article 7 and 309 of the Amsterdam Convention provides the proceeding of suspension of members unless they meet the obligations ${ }^{37}$.

\section{Funding of International Organizations}

An organization functioning normally requires funding, which can be done in different ways in: money and material goods. While International Organizations` final form of financial resources is classification in, funding through obligatory

${ }^{26}$ Read more at http://www.wipo.int/portal/en/index.htm/Riza, Arif E Drejta e Organizatave Ndërkombëtare dhe Organizatat Ndërkombëtare, botimi I page 252

${ }^{27}$ Riza, Arif E Drejta e Organizatave Ndërkombëtare dhe Organizatat Ndërkombëtare, botimi I f. 70

${ }^{28}$ The formal criteria's are criterias the ones that the states should pass in order to become a member of one Organization example: Article 6 of the UN statute foresees that one state to become a member of UN shall fulfill the criterias from Article 4 andwith recommendation by Security Council of UN.

${ }^{29}$ The material criteria's for example: with UN statute, article 4, one state that request membership shall show the willingness and ability to provide peace.

30Usually the regular member of International Organizations can be only states that hold full international subjectivity

${ }^{31}$ The statute of pre member state have only the states which do not have full rights but intend to become members with full rights.

${ }^{32}$ The statute of observer have states that want to observe at the Organization and the possibility of membership.

${ }^{33}$ The material criteria's that shall be fulfilled by one state in order to leave the membership.

${ }^{34}$ The limit of time that one state should follow in order to leave the organization shall be noticed early ( 2 years example Nations Union, or from FAO 4 years).

${ }^{35}$ Kock/Fischer, Das Rechtder Intenationalen Organisationen p. 543

${ }^{36}$ Studie in International Law, 1979, page 3

37Wolfgang Graf Vitzthu, Volerrecht, 4 Auglage page 303 
contributions, financed by voluntary contributions (donations) ${ }^{38}$, financed by borrowing, and the Organization's ${ }^{39}$ own contributions.

In some International Organization the level of contributionsis known and cannot be higher than half of the total, while in some others the amount of obligatory contributions is equally determined e.g. OPEC, in some Organizational contributions set by the degree of development, namely on the basis of income per head of population, in some cases it is determined based on the economic strength of a country.

\section{Regional Organizations}

After the breakup of Yugoslavia, after beginning of the wars in former Yugoslavia, the role of Regional Organizations was big enough that there were efforts to prevent war in the former Yugoslavia or prevent war in general. For example OSCE with its mission participated as observers in the former Yugoslavia with a very broad mission. Also WEU ${ }^{40}$ police mission in Balkans 'States, the European Union's contributions for the Balkan states, and NATO, which presented in the former states of Yugoslavia. But her role was decisive when its forces bombed military targets of the Union of SerbiaMontenegro, due to the war in Kosovo. The role of these Organizations continues to be very large, especially the European Union with its investments in Balkans ${ }^{41}$ countries and its presence through the EULEX mission in Kosovo.

\section{Kosovo's membership in the International Organizations}

Kosovo as a new state which had declared its independence on 17.02 .2008 began its efforts to join the International Organization. Before the declaration of independence due to its unresolved International status Kosovo was only in the CEFTA ${ }^{42}$ agreement.After Kosovo's declaration of Independence it was accepted at three key International Financial Organizations and so in the World Bank, the International Monetary Fund and the IBA ${ }^{43}$. Since the international community urged Kosovo and Serbia to enter into negotiations to avoid blocking the process of Kosovo's membership in the Regional Organizations, in Brussels the agreement was reached between the representatives of the European Union Kosovo and Serbia to give the opportunity to the Kosova for possible membership in some Regional organizations with footnote. Therefore theRepublic of Kosovo is a member of 35 International and Regional Organizations or has entered into agreements with some of them. (See below).

Table 1: List of regional and international organizations where the Republic of Kosovo is a member / observer I participant

\begin{tabular}{|l|l|c|c|}
\hline \multicolumn{2}{|l|}{ Name of Organization } & ABV & Year of membership \\
\hline 1 & The World Bank (UN specialized agency) & WB & 2009 \\
\hline 2 & IMF (UN specialized agency) & IMF & 2009 \\
\hline 3 & International Bar Association & IBA & 2009 \\
\hline 4 & Central European Free Trade Agreement & CEFTA & 2007 \\
\hline 5 & Vienna Economic Forum & VEF & 2009 \\
\hline 6 & European Bank for Reconstruction and Development & EBRD & 2012 \\
\hline 7 & European Investment Bank & EID & 2013 \\
\hline 8 & Council of Europe Development Bank & CEB & 2013 \\
\hline 9 & Regional Cooperation Council & RCC & 2013 \\
\hline 10 & SEE Investment Committee & SEEIC & 2012 \\
\hline 11 & The Regional Rural Development Standing Working Group of South East Europe & RRDWSG & 2012 \\
\hline 12 & SEE Trade Union Forum & SEETUF & 2012 \\
\hline 13 & Centre for e-Governance Development & CeGD & 2012 \\
\hline
\end{tabular}

\section{${ }^{38}$ Example: UNDP, UNICEF, UNHCR}

${ }^{39}$ Sole contribution are those contribution coming from revenues of Organizations, for example rents.

${ }^{40}$ WEU (Western European Union) European Western Union was aregional European organization until June 2011, incorporated into European Union.

41The Germany as the Leader of European Union organized Samite on 28 August 2014 with 8 countries from Balkan.

${ }^{42}$ CEFTA is not International Organization or Regional but is only trading agreement because does not fills the criteria's to be as such.

${ }^{43}$ IBA International Bar Association. 


\begin{tabular}{|l|l|c|c|}
\hline 14 & Electronic South Eastern Europe Initiative & eSEE & 2012 \\
\hline 15 & Energy Community Secretariat & ECS & 2012 \\
\hline 16 & South East Europe Transport Observatory & SEETO & 2012 \\
\hline 17 & Network of Associations of Local Authorities of SEE & NALAS & 2012 \\
\hline 18 & South East European Public Private Partnership Network & SEEPPPN & 2012 \\
\hline 19 & US - Adriatic Charter (A5) & AC & 2012 \\
\hline 20 & Education Reform Initiative of South Eastern Europe & ERI SEE & 2012 \\
\hline 21 & RCC Task Force Fostering and Building Human Capital & TF FBHC & 2012 \\
\hline 22 & Regional School of Public Administration & ReSPA & 2013 \\
\hline 23 & South East European Center for Entrepreneurial Learning & SEECEL & 2012 \\
\hline 24 & Vise grad Group & VG & 2012 \\
\hline 25 & Human Dynamics & HD & 2012 \\
\hline 26 & Western Balkans Investment Framework & WBIF & 2011 \\
\hline 27 & Brdo Process & BP & 2010 \\
\hline 28 & Energy Community & EC & 2011 \\
\hline 29 & Regional Environmental Network for Accession & RENA & 2012 \\
\hline 30 & Task Force for Fostering and Building Human Capital & TFFBHC & 2013 \\
\hline 31 & ISIS Program meSecretariat & ISIS ECAA & 2012 \\
\hline 32 & Investment Compact for SEE & ICSEE & 2012 \\
\hline 33 & NATO Parliamentary Assembly & NATO PA & 2014 \\
\hline 34 & Venice Commission (CoE) & VC CoE & 2014 \\
\hline 35 & South-East European Cooperation Process & SEECP & 2014 \\
\hline 36 & Migration, Asylum, Refugees Regional Initiative & MARRI & 2014 \\
\hline
\end{tabular}

Source: Ministry of Foreign Affairs in the Republic of Kosovo for International Organizations / Department for International Organizations - MFA; Updated on: 26.06.20141

\section{Conclusion}

As a significant number of International Organizations does not require a state to be a member of the UN, the Republic of Kosovo has the best opportunity to seek membership. Although the membership in International Organizations has a great importance, they often are larger and cost the state in this case RK should consider the benefits of these Regional and International Organizations, e.g., in the year when this paper has been written it wasn't appropriate for Kosovo to join the NATO even if the opportunity would be unavoidable, because Kosovo has security provided by NATO well enough even with not being its member, because as membership itself also carries with it particular budget of RK.

Therefore it would be advisable for the Government of Kosovo to be focused on Organizations where Kosovo will have a direct benefit, e. $\mathrm{g}$ It should be a priority attempt to quickly join the European Union, as now Kosovo is a memeber to a number of International Financial Organizations (IMF, World Bank / WB, International Finance Corporation I FIC and the International Association for Development / IDA) and the regional (European Bank for Reconstruction and Development / EBRD, the European Investment Bank / EID, etc

\section{References}

Archer, Internatioanl Organisations, 2004.

Boli, Thomas, Art, INGOs, 1999.

Chritian, Tiejet, Internationales Verwaltungshandeln, Berlin, 2001.

GrudaZenullah, International Public Law.

Iriy, Global Community, 2002.

Karns/Mingst, Internationale Organizations 2010, F. 8 Jacobson, Networks

Kock/Fischer, Das Recht der Intenationalen Organisationen.

Ministria e Republikëssë Kosovëspër PunëtëJashtme- Departamentipërorganizatatndërkombëtare/Department for International Organizations - MFA.

RizaArif, E Drejta e OrganizataveNdërkombëtaredheOrganizatatNdërkombëtare, botimi i I.

Studie in International Law, 1979.

Wallace- Dinger, Intergovermental Organization, 1970.

White, International Nongovermental Organizations, 1968. 
White, Lyman Cromwell: International Non-Governmental Organizations: Their Purposes, Methods, and Accomplishments, New York 1968.

Wolfgang Graf Vitzthu, Volerrecht, 4 Auglage.

Wong, Laura E.: Art. "IGOs", in: Akira Iriyeu.a. (Hg.): The Palgrave Dictionary of Transnational History: From the Mid-19th Century to the Present Day, London 2009.

http://gdz.sub.uni goettingen.de/dms/load/img/?PPN=PPN546672892\& IDDOC= 316027

http://www.uia.org/sites/dev.uia.be/files/misc_pdfs/ybvol5_lookinside.pdf 
